\title{
Model Pembelajaran Gerak Dasar Melompat melalui Modifikasi Permainan Tradisional Engklek pada Anak Sekolah Dasar
}

\author{
Guntur Firmansyah ${ }^{1}$, Ervin Dwi Rahayu ${ }^{1}$, Irwansyah ${ }^{1}$ \\ ${ }^{1}$ Pendidikan Jasmani, Kesehatan, dan Rekreasi IKIP Budi Utomo Malang, Jawa Timur, Indonesia
}

\section{Info Artikel}

SejarahArtikel:

Diterima Desember 2018

Disetujui Maret 2019

Dipublikasikan Mei 2019

\section{Keywords:}

Gerak Dasar Melompat, Permainan Tradisional Engklek

\begin{abstract}
Abstrak
Penelitian ini bertujuan untuk membuat model pembelajaran gerak dasar melompat melalui modifikasi permainan tradisional yang menyenangkan, menarik, bervariasi, interaktif dan efektif dan membantu siswa dalam meningkatkan gerakan motorik kasar pada anak-anak sekolah dasar. Dalam penelitian ini, peneliti menggunakan model penelitian dan pengembangan. Media pembelajaran diperlukan data sebesar $81,25 \%$, ahli pembelajaran sebesar $75,00 \%$, model ahli pembelajaran memperoleh hasil $87,50 \%$, uji coba dengan 8 subyek (kelompok kecil) 89,84\%, uji coba lapangan dengan subjek $3084,38 \%$, uji coba produk akhir $83,13 \%$. Dapat dinyatakan bahwa model pembelajaran gerak dasar melompat melalui modifikasi permainan tradisional lutut untuk meningkatkan gerakan motorik kasar pada anak-anak sekolah dasar dapat digunakan.
\end{abstract}

\begin{abstract}
This study aims to design of basic jumping movement learning models through modification of traditional games in order to fun, interesting, varied, interactive, effective and help students improve gross motor skills in elementary school student. In this study, researchers used a development model referring to research and development. Learning media required data at $81.25 \%$, learning experts at $75.00 \%$, learning expert models obtained $87.50 \%$, trials with 8 subjects (small groups) $89.84 \%$, first trials with subjects $3084,38 \%$, the final product test $83.13 \%$. This reseach conlude that the basic jumping movement learning through the modification of traditional knee games to improve gross motor skills in elementary school student can be used.
\end{abstract}




\section{PENDAHULUAN}

Pembelajaran pendidikan jasmani pada tingkat sekolah dasar kelas bawah di Indonesia diarahkan pada pembelajaran penguasaan gerak dasar, perkembangan mental dan penguasaan pengetahuan. Sehingga diharapkan pelajaran pendidikan jasmani dapat memberikan sumbangan yang positif untuk perkembangan dan pertumbuhan peserta didik. Disamping itu, diharapkan gerak, mental dan otak peserta didik dapat berkembang dan berjalan secara seimbang. Melalui aktivitas bermain, otak dapat dilatih untuk berpikir secara cepat, terkoordinasi dan tepat untuk mencari solusi atau penyelesaian dari kesulitan yang ada pada suatu permainan. Keseimbangan antara kemanpuan berfikir dan keluwesan gerak tubuh memegang peranan penting bagi proses tumbuh kembang anak.

Berbagai faktor yang mempengaruhi proses perkembangan anak, salah satunya yaitu perkembangan gerak anak. Secara alamiah setiap anak harus memiliki gerak motorik yang bagus karena hal itu sangat dibutuhkan sebagai salah satu penunjang proses perkembangan anak nantinya. Untuk menunjang proses perkembangan keterampilan gerak yang harus dikuasai karena sangat diperlukan oleh setiap anak yaitu keterampilan gerak kasar (gross motor skill) dan keterampilan gerak halus (fine motor skill). Motorik kasar adalah gerakan anggota tubuh yang meibatkan penggunaan sebagian atau seluruh otot-otot besar yang ada didalam tubuh yang terpegaruh dari kematangan dirinya (Triatmoko, Purnomo, \& Yunitaningrum, 2016) (Sultoni, et.al, 2018). Sedangkan pembelajaran motorik kasar yang diadakan di sekolah merupakan pembelajaran gerakan fisik yang membutuhkan keseimbangan dan koordinasi anggota tubuh, sebagian, atau seluruh anggota tubuh. Contohnya, berlari, berjalan, melompat, menendang, berlari dan lain-lain.

Permainan tradisional memang memiliki dampak yang positif untuk perkembangan dan pertumbuhan anak karena memberikan ruang gerak bebas yang sangat luas. Dibandingkan dengan permainan yang ada pada era sekarang dalam bentuk virtual atau pemainan yang dimainkan secara daring yang dapat mengurangi aktivitas gerak karena permainan hanya dimainkan dengan cara duduk selama berjam-jam.

Dengan semakin berkembangnya teknologi dalam bentuk permainan-permainan canggih dikhawatirkan permainan tradisional yang sudah sejak lama dimainkan oleh anakanak akan ditinggalkan dan dilupakan. Oleh karena itu, pelestarian permainan tradisional penting untuk dilakukan dengan cara memperkenalkan dan memainkan permainan tradisional bersama anak, disertai dengan upaya penyadaran kepada pihak-pihak terkait khususnya orang tua akan bahaya games (Nur, 2013).

Salah satu bentuk permainan tradisional yang mudah untuk dimainkan oleh anak-anak adalah permainan engklek. Permainan ini sangatlah mudah untuk dimainkan dan tidak membutuhkan biaya yang mahal serta alat bermain yang bisa dijumpai dimana saja. Engklek adalah salah satu warisan leluhur dalam bentuk permainan yang rekreatif, kreatif, permainan yang mengarah pada peningkatan afektif, kognitif serta psikomotorik anak-anak maka diperlukan dan diharapakan adanya pelestarian yang harus dilakukan oleh semua lapisan masyarakat. 
Berdasarkan data awal yang dilakukan melalui observasi, dijumpai penggunaan model pembelajaran yang digunakan kurang bervariasi. Model pembelajaran melompat yang digunakan oleh guru olahraga kurang menarik dan model pembelajaran yang diterapkan kurang efektif untuk meningkatkan gerak motorik anak. Berdasarkan analisis kebutuhan awal yang dilakukan kepada guru ditemukan keantusiasan dari siswa saat guru memberikan model pembelajaran gerak dasar melompat untuk meningkatkan gerak motorik kasar pada anak sebesar $66,67 \%$. Sedangkan rata-rata siswa yang mampu mempraktekkan model pembelajaran gerak dasar melompat untuk meningkatkan gerak motorik kasar pada anak sebesar 50-70 \%. Berdasarkan analisis kebutuhan awal yang dilakukan kepada siswa terdapat sebanyak $58,83 \%$ menyatakan pada saat mempraktekkan model pembelajaran gerak dasar melompat merasa bingung dan 47,50\% siswa menyatakan model pembelajaran gerak dasar melompat yang dilakukan membosankan.

Dari penelitian sebelumnya, faktor-faktor yang mempengaruhi perkembangan motorik anak diantaranya adalah 1) usia anak karena semakin tua usia anak maka semakin baik perkembangan motoriknya, 2) pola pengasuhan orang tua di rumah khususnya oleh ibu, 3) program sekolah yang diikuti anak diantaranya metode pengajaran dan program pengajaran, 4) sarana dan prasarana sekolah yang beragam dan lengkap (Hastuti, 2009). Dari penelitian lainnya menyimpuakan bahwa beberapa faktor yang mempengaruhi perkembangan anak adalah stimulasi yang diberikan oleh orang tua dan faktor gizi (Dewi \& Winarsih, 2017). Sedangkan berdasarkan penelitian (Wardika \&
Indahwati, 2017) menyimpulkan bahwa tidak ada perbedaan perkembangan motorik anak berdasarkan letak geografis yaitu anak yang tinggal di daerah dataran rendah dan anak yang tinggal di daerah pesisir.

Berdasarkan latar belakang yang telah dipaparkan tersebut, diperlukan adanya pengembangan model pembelajaran gerak dasar melompat dalam pendidikan jasmani kesehatan dan rekreasi melalui modifikasi permainan tradisional engklek yang menyenangkan, menarik, variatif, interaktif dan efektif serta membantu siswa dalam meningkatkan gerak motorik kasar pada anak sekolah dasar. Penelitian ini bertujuan untuk membuat model pembelajaran gerak dasar melompat dalam pendidikan jasmani kesehatan dan rekreasi melalui modifikasi permainan tradisional engklek yang menyenangkan, menarik, variatif, interaktif dan efektif serta membantu siswa dalam meningkatkan gerak motorik kasar pada anak sekolah dasar.

\section{METODE PENELITIAN}

Dalam penelitian ini peneliti mengunakan model pengembangan yang mengikuti model research and development (Winarno, 2011). Adapun tahapan-tahapan penelitian terdiri dari sepuluh tahapan pelaksanaan antara lain: 1) melakukan penelitian yang merupakan analisis kebutuhan melalui observasi pada 3 guru pjkr dan 30 siswa sekolah dasar, 2) melakukan perencanaan pembuatan model pembelajaran gerak dasar melompat melalui modifikasi permainan tradisional engklek, 3) pengembangan produk serta pengevaluasian terhadap para ahli. Produk awal yang sudah terbentuk dijustifikasi oleh 1 orang ahli media pembelajaran, 1 orang 
ahli pembelajaran penjas, dan 1 orang ahli model pembelajaran, 4) langkah selanjutnya, produk yang telah dijustifikasi oleh para ahli diuji cobakan pada siswa sekolah dasar dengan melibatkan 8 subyek uji coba, 5) revisi pertama hasil uji coba dan melakukan perbaikan atau penyempurnaan hasil uji coba sesuai dengan hasil dari uji coba kelompok kecil, 6) uji coba lapangan dilakukan pada siswa sekolah dasar dengan melibatkan 30 subyek uji coba, 7) revisi kedua hasil uji coba dan memperbaiki atau menyempurnakan hasil uji coba sesuai dengan hasil dari uji coba lapangan, 8) uji coba produk akhir atau uji coba lapangan pada siswa sekolah dasar dengan melibatkan 40 subyek uji coba, 9) merevisi hasil uji coba dan memperbaiki atau menyempurnakan hasil uji coba sesuai dengan hasil dari uji coba lapangan, 10) diseminasi dan implementasi.

Proses pengumpulan data pada penelitian ini menggunakan instrumen penelitian berupa observasi, dokumentasi dan penyebaran angket. Tahapan pengumpulan data dari proses ujicoba yaitu uji coba kelompok kecil, ujicoba lapangan dan ujicoba akhir. Metode pengambilan subyek yaitu menggunakan prosedur yang dilakukan dalam uji coba ini adalah (1) memberikan produk model pembelajaran gerak dasar melompat melalui modifikasi permainan tradisional engklek untuk diamati dan dipahami (2) siswa mempraktikan model pembelajaran gerak dasar melompat melalui modifikasi permainan tradisional engklek yang telah diamati (3) setelah itu siswa diminta memberikan tanggapan tentang produk yang telah diamati dengan menggunakan kuesioner. Hasil data yang diperoleh dari uji coba dianalisis dan digunakan untuk penyempurnaan produk model pembela- jaran gerak dasar melompat melalui modifikasi permainan tradisional engklek.

Instrumen pengumpulan data yang digunakan dalam pengumpulan data pada penelitian pengembangan ini adalah sebagai berikut: 1) observasi, observasi atau pengamatan dipergunakan untuk memperolah informasi awal tentang kebutuhan model pembelajaran gerak dasar melompat melalui modifikasi permainan tradisional engklek untuk meningkatkan gerak motorik kasar pada anak sekolah dasar, yang dilakukan berdasarkan temuan dan pengalaman peneliti selama di lapangan, 2) dokumentasi, berupa bahan-bahan pustaka yang relevan yang akan menjadi tujuan dan memberikan masukan yang signifikan dalam pengumpulan bahan pengembangan model pembelajaran gerak dasar melompat melalui modifikasi permainan tradisional engklek untuk meningkatkan gerak motorik kasar pada anak sekolah dasar, antara lain buku literatur, bahan seminar, buku pegangan pelatih, dan materi dari website, 3) angket, angket merupakan teknik pengumpulan data yang dilakukan dengan cara memberikan seperangkat pertanyaan atau pernyataan tertulis kepada responden untuk dijawab. Angket tersebut diberikan kepada ahli media pembelajaran, ahli pendidikan jasmani kesehatan dan rekreasi, dan ahli model pembelajaran dan siswa SDN Kota Lama 2 Malang, SDN Kota Lama3 Malang dan SDN Kota Lama 4 Malang yang isinya di bedakan sesuai dengan fungsi dan kebutuhan. Angket untuk ahli isi dititik beratkan kepada produk yang dikembangkan, sedangkan untuk guru dan siswa dititik beratkan pada analisis kebutuhan dan pemanfaatan produk yang dikembangkan. 
Setelah data diperoleh kemudian dilakukan analisis data dari setiap subjek yang meliputi uji coba dan evaluasi ahli dengan pedoman penskoran yang dirujuk dari (Creswell, 2010). Untuk mengolah data menggunakan teknik analisis kualitatif dan deskriptif berupa persentase. Analisis kualitatif digunakan untuk menganalisis hasil pengumpulan data dari tinjauan para ahli menggunakan pendekatan kualitatif. Analisis deskriptif dalam bentuk persentase digunakan untuk menganalisis hasil dari proses pengumpulan data uji coba (Bakhtiar, 2010).

\section{HASIL PENELITIAN}

Pada Dari penelitian ini diperoleh hasil yang dapat dilihat pada tabel penyajian data untuk analisis kebutuhan yang diberikan kepada 3 guru penjas dan 30 siswa SDN Kota Lama 2 Malang, SDN Kota Lama 3 Malang dan SDN Kota Lama 4 Malang, evaluasi ahli dan uji coba produk.

Tabel 1. Penyajian Data Hasil Analisis Kebutuhan 3 Guru

\begin{tabular}{ll}
\hline Temuan \\
\hline - & $\begin{array}{l}\text { Keantusiasan dari siswa saat guru mem- } \\
\text { berikan model pembelajaran gerak dasar } \\
\text { melompat untuk meningkatkan gerak mo- } \\
\text { torik kasar pada anak sebesar } 66,67 \%,\end{array}$ \\
- & $\begin{array}{l}\text { Rata-rata siswa yang mampu mempraktek- } \\
\text { kan model pembelajaran gerak dasar me- } \\
\text { lompat untuk meningkatkan gerak motorik } \\
\text { kasar pada anak sebesar 50-70 \%, }\end{array}$ \\
Setuju jika dilakukan pengembangan model \\
pembelajaran gerak dasar melompat dalam \\
untuk meningkatkan gerak motorik kasar \\
pada anak secara sintetik sehingga kompe- \\
tensi yang diharapkan bisa tercapai dengan \\
presentase sebesar 75\%.
\end{tabular}

Tabel 2. Penyajian Data Hasil Analisis Kebutuhan 30 Siswa

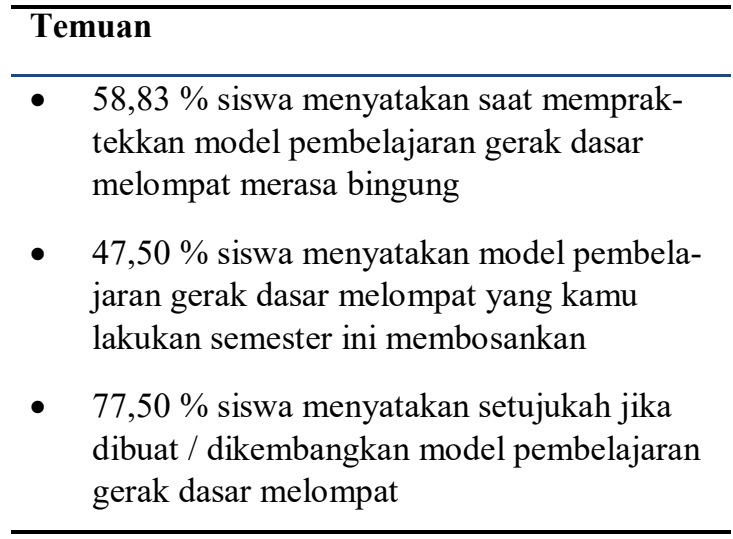

Tabel 3. Penyajian Data Hasil Analisis Kebutuhan 30 Siswa

\begin{tabular}{ll}
\hline Temuan & \\
\hline Dari evaluasi ahli media & pembelajaran \\
diperoleh hasil $81,25 \%$ & maka dapat \\
dinyatakan bahwa model pembelajaran \\
gerak dasar melompat melalui modifikasi \\
permainan tradisional engklek untuk \\
meningkatkan gerak motorik kasar pada \\
anak sekolah dasar dapat digunakan dan siap \\
untuk diujicobakan \\
Memperbesar ukuran petak pada produk \\
model pembelajaran engklek
\end{tabular}

Tabel 4. Penyajian Data Evaluasi Ahli Media Pembelajaran

\section{Temuan}

- Dari evaluasi ahli media pembelajaran diperoleh hasil 81,25 \% maka dapat dinyatakan bahwa model pembelajaran gerak dasar melompat melalui modifikasi permainan tradisional engklek untuk meningkatkan gerak 'motorik kasar pada anak sekolah dasar dapat digunakan dan siap untuk diujicobakan

- Memperbesar ukuran petak pada produk model pembelajaran engklek

Evaluasi ahli media pembelajaran memperoleh data sebesar $81,25 \%$, ahli pembelajaran sebesar 75,00\%, ahli model pembelajaran 
diperoleh hasil 87,50\%, uji coba dengan 8 subjek (kelompok kecil) 89,84 \%, uji coba lapangan dengan subjek sebanyak 30 anak $84,38 \%$, uji coba produk akhir dengan jumlah subyek 40 anak $83,13 \%$.

Tabel 5. Penyajian Data Evaluasi Ahli Pembelajaran Penjas

\begin{tabular}{ll}
\hline Temuan \\
\hline - & $\begin{array}{l}\text { Dari evaluasi ahli pembelajaran diperoleh } \\
\text { hasil 75,00 \% maka dapat dinyatakan } \\
\text { bahwa model pembelajaran gerak dasar } \\
\text { melompat melalui modifikasi permainan } \\
\text { tradisional engklek untuk meningkatkan } \\
\text { gerak motorik kasar pada anak sekolah } \\
\text { dasar dapat digunakan dan siap untuk } \\
\text { diujicobakan }\end{array}$ \\
- & $\begin{array}{l}\text { Penggunaan kaki ketika bermain berganti- } \\
\text { an kaki kanan dan kiri }\end{array}$ \\
- $\quad$ Waktu bermain harus ditentukan \\
- Jumlah pemain pada saat bermain \\
Video mulai dari awal sampai dengan \\
pemain dapat rumah \\
\hline
\end{tabular}

Tabel 6. Penyajian Data Evaluasi Ahli Model Pembelajaran

\begin{tabular}{l}
\hline Temuan \\
\hline Dari evaluasi ahli model pembelajaran di- \\
peroleh hasil $87,50 \%$ maka dapat dinya- \\
takan bahwa model pembelajaran gerak \\
dasar melompat melalui modifikasi \\
permainan tradisional engklek untuk \\
meningkatkan gerak motorik kasar pada \\
anak sekolah dasar dapat digunakan dan \\
siap untuk diujicobakan \\
\hline
\end{tabular}

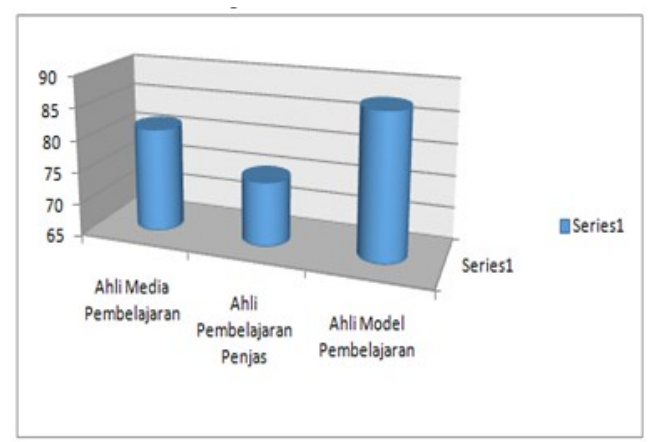

Gambar 1. Hasil Evaluasi Ahli

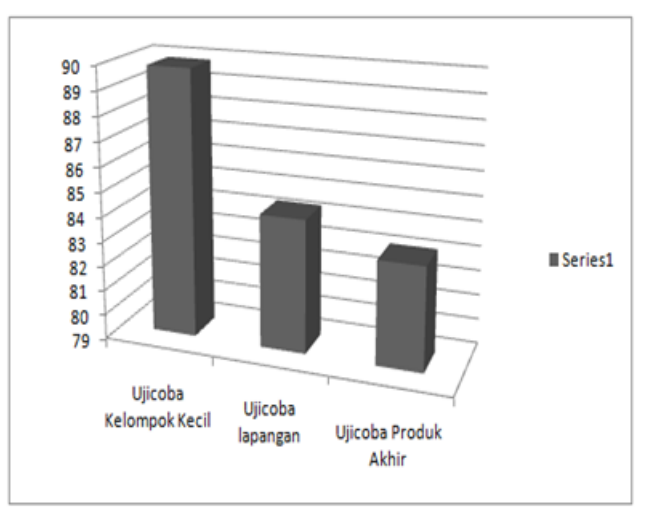

Gambar 1. Hasil Uji Coba Produk

Hasil penelitian ini mendukung penelitian -penelitian pengembangan model pembelajaran melompat (Anggi Feri Setiadi, Rumini, 2015) (Bakhtiar, 2010), (Ardhika, 2012) menggunakan permainan rangkaian 3 pos, (Anggi Feri Setiadi, Rumini, 2015) melalui permainan lompat bergandengan, (M. B. Suroso, 2015) menggunakan permainan lompat kangguru. Data dan hasil penelitian yang telah diperoleh bisa menjadi tambahan dan sumbangan pada penelitian yang membahas engklek yang berkaitan dengan gerak motorik pada anak. Yang menjadi pembeda dari hasil penelitian ini adalah bentuk dari engklek yang dimainkan serta cara bermain yang lebih menantang anakanak sehingga anak-anak menjadi lebih tertarik, antusias serta lebih semangat untuk belajar gerak.

\section{KESIMPULAN}

Model pembelajaran gerak dasar melompat melalui modifikasi permainan tradisional engklek untuk meningkatkan gerak motorik kasar pada anak sekolah dasar dapat digunakan 


\section{DAFTAR PUSTAKA}

Anggi Feri Setiadi, Rumini, H. W. (2015). Model Pembelajaran Gerak Dasar Melompat Dalam Penjasorkes Melalui Permainan Lompat Bergandeng Pada Siswa Kelas Iv Sekolah Dasar. Journal of Physical Education, Sport, Health and Recreations, 4(5), 1807-1813.

Ardhika, D. F. (2012). Upaya Meningkatkan Hasil Belajar Gerak Dasar Lompat Melalui Modifikasi Permainan Tradisional Engklek Pada Siswa Kelas Ii Sd Negeri 2 Jeruk Kabupaten Blora Tahun 2013/2014. Journal of Physical Education, Sport, Health and Recreations, 1 (2), 648-655.

Bakhtiar, W. (2010). Pembelajaran Teknik Dasar Lompat Jauh Melalui Permainan Rangkaian 3 Pos Pada Siswa Kelas V Sd Negeri Bumijawa 07 Kecamatan Bumijawa Kabupaten Tegal Tahun 2013. Journal of Physical Education, Sport, Health and Recreations, 21(1), 1 -11. Retrieved from http:// periodicos.uem.br/ojs/index.php/ RevEducFis/article/view/6713/5702

Creswell, J. . (2010). ). Research Desaign Pendekatan Kualitatif, Kuantitatif, dan Mixed. Yogyakarta: Pustika Pelajar.

Dewi, A. K., \& Winarsih, B. D. (2017). Hubungan Peran Orangtua Dalam Mesntimulasi Perkembangan Dengan Perkembangan Motorik Usia Prasekolah Di Tk Pertiwi Desa Kesambi Kab. Kudus. In PROSIDING HEFA (Health Events for All) Publikasi Hasil Riset Kesehatan untuk Daya Saing Bangsa (pp. 38-43).

Hastuti, D. (2009). STIMULASI PSIKOSOSIAL PADA ANAK KELOMPOK BERMAIN DAN PENGARUHNYA PADA PERKEMBANGAN MOTORIK, KOGNITIF, SOSIAL EMOSI, DAN MORAL/KARAKTER ANAK. Jur. Ilm. Kel. Dan Kons, 2(1), 41-56.

Ilham. (2011). Pengaruh Permainan Tradisional Terhadap Peningkatan Kemampuan Lompat Jauh Tanpa Awalan Siswa Sekolah Dasar Negeri No. 52/Iv Kota Jambi. Jurnal Penelitian Universitas Jambi Seri Humaniora, 13(2), 19-24. Retrieved from Traditional games,
Nur, H. (2013). Membangun Karakter Anak Melalui Permainan Anak Tradisional. Pendidikan Karakter, 3(1).

Sultoni, K., Suherman, A., \& Wibowo, R. (2018). Increasing Gross Motor Skill Through Fundamental Skill Development Program. ACTIVE: Journal of Physical Education, Sport, Health and Recreation, 7(1), 39-43.

Suroso, M. B. (2015). Permainan Lompat Kanguru Untuk Meningkatkan Hasil Belajar Lompat Jauh Gaya Jongkok. Journal of Physical Education, Sport, Health and Recreations, 4(9), 2089-2093.

Triatmoko, A., Purnomo, E., \& Yunitaningrum, W. (2016). Kemampuan motorik kasar siswa kelas v sdn 21 sungai kakap kabupaten kubu raya. Jurnal Pendidikan, $1-11$.

Wardika, F., \& Indahwati, N. (2017). PROFIL KEMAMPUAN MOTORIK BERDASARKAN KONDISI GEOGRAFIS DI SEKOLAH DASAR NEGERI 4 TAPANREJO KECAMATAN MUNCAR KABUPATEN BANYUWANGI, $5,418-424$.

Winarno, M. E. (2011). Metodologi Penelitian Dalam Pendidikan Jasmani. Malang: Media Cakrawala Utama Press. 